\title{
The role of mafic magmatism in age specification of Devonian continental trough deposits: evidence from the Minusa Basin, western Siberia, Russia
}

\author{
GELIY S. FEDOSEEV
}

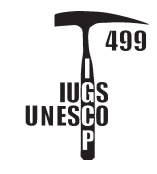

\begin{abstract}
In the Devonian the Minusa Intermountain Trough (Basin) of Siberia represented a rift structure that was filled with rocks which now occur as strata-like bodies interpreted to be of volcanic origin. The character of the mafic rocks including their upper contacts and geochronological dating, using $\mathrm{Rb} / \mathrm{Sr},{ }^{40} \mathrm{Ar} /{ }^{39} \mathrm{Ar}$, and $\mathrm{U} / \mathrm{Pb}$ methods, suggests their sill or subvolcanic nature. Porphyry and dolerite sills and basalt formed later (385-405 Mya) than felsic and andesitic volcanic rocks (402-448 Mya). Because these bodies were earlier considered as volcanic flows, it is important to revise the geological succession of the Devonian formations dominated by mafic igneous rocks. Key words: Early Devonian, stratigraphy, geochronology, basalt, dolerite and porphyry sills, Minusa Basin, Russia.
\end{abstract}

FEDOSEEV, G.S. 2008. The role of mafic magmatism in age specification of Devonian continental trough deposits: evidence from the Minusa Basin, western Siberia, Russia. Bulletin of Geosciences 83(4), 473-480 (3 figures, 2 tables). Czech Geological Survey, Prague. ISSN 1214-1119. Manuscript received September 19, 2006; accepted in revised form August 26, 2008; issued December 31, 2008.

Geliy S. Fedoseev, Institute of Geology and Mineralogy named after V.S. Sobolev, Siberian Branch of Russian Academy of Sciences, Koptug Av. 3; Novosibirsk State University, Pirogov st. 2, 630090 Novosibirsk, Russia; fedoseev@uiggm.nsc.ru

The Minusa Intermountain Trough is a fragment of an intracontinental sedimentary basin dominated by Devonian and Carboniferous sedimentary infill, with subordinate Triassic and Jurassic sedimentary rocks. Such basins commonly form due to the regional extension of the Earth's crust. Geodynamically, they can be related to back-arc basin structures or to an active continental margin, as existed in the region during Devonian time (Krasnov \& Ratanov 1972, Levchenko 1975). Igneous rocks with varying compositions in these basins are dominated by felsic rocks with subordinate mafic bimodal varieties. The mafic varieties are commonly considered initial members of volcanic assemblages. Large occurrences of mafic rocks are considered autonomous formations (Ton, Marchengash, and other formations) and belong to the Lower Devonian Byskar succession ("Byskar Series"). However, this point of view is not generally agreed upon: previously it was shown that the dolerites and porphyry are not effusive rocks (Krasnov \& Fedoseev 2000). That is more essential for correction of the age of the host rocks, which was established using paleontological data. The mafic rocks and flora and fauna in the sedimentary rocks are considered to be of a similar age if the "extrusive paradigm" is proven. Otherwise ("intrusive paradigm"), the age of the bedded mafic rocks should be younger (Fedoseev 2008).
The recognition of mafic bedded bodies occurring within sedimentary and volcano-sedimentary deposits is possible only with careful study of their upper contacts to avoid misinterpretation of the nature of shallowly-intruded mafic rocks. Therefore, the main focus of this study was to develop a set of distinctive geological criteria that would distinguish lava flows and sheets from shallow-depth sills, and then to apply them to the Devonian rocks in the Minusa Trough.

\section{Depth of formation of Devonian mafic igneous rocks}

The geology of the mafic strata-like bodies hosted by the Lower Devonian sedimentary rocks in the Minusa Trough has previously been mischaracterized. The bodies have traditionally been described as volcanic rocks because of their vitreous appearance, amygdaloidal texture, 'cold' contacts with the hosting rocks, columnar jointing, and other features. Moreover, they have no high-temperature contacts with host rocks. We recognize at least three possible reasons for the misinterpretation of the mode of formation of the thin mafic strata-like bodies.

The first reason is a traditional view of some authors who consider that mafic volcanism is strictly related to the 


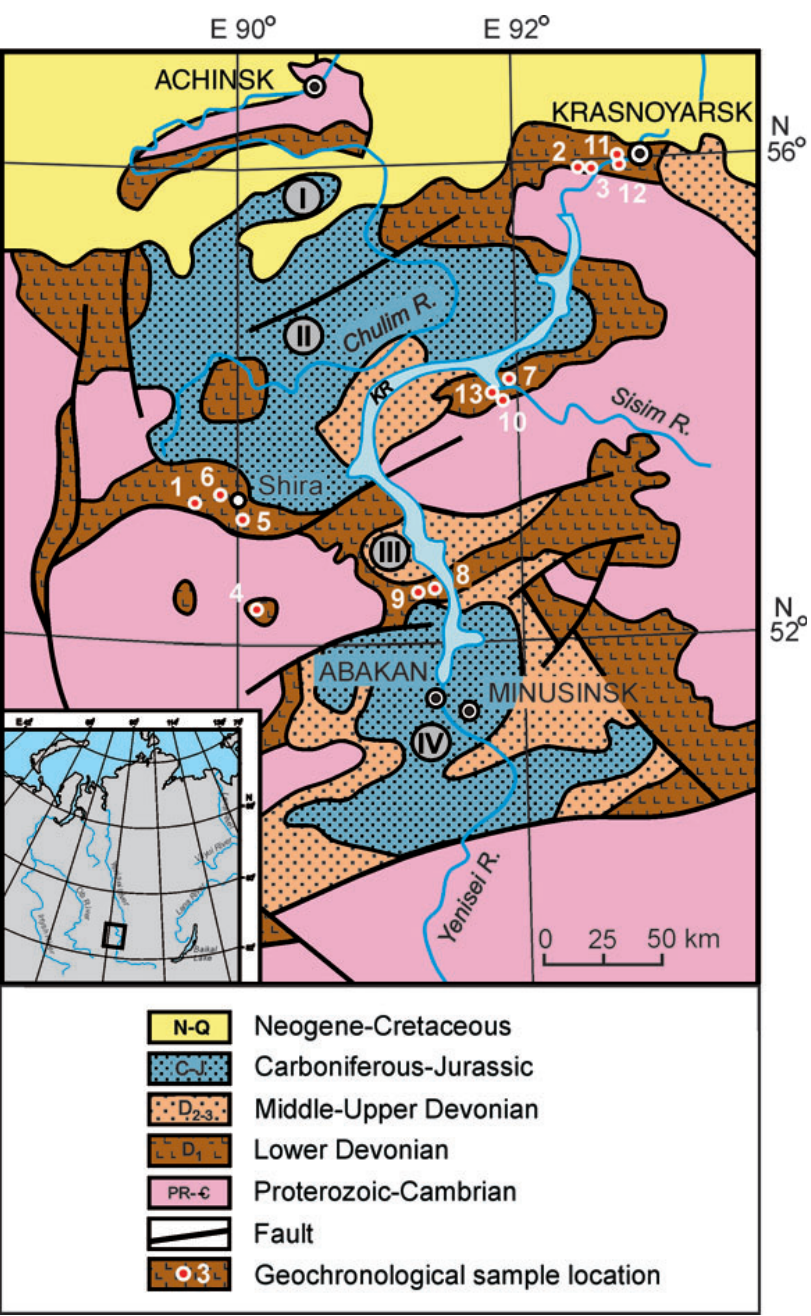

Figure 1. Geologic map of the study area in the Minusa Intermontaine Trough. Roman numerals correspond to depressions: I - Nazarovo, II - Chebakovo-Balakhtino, III - Syda-Erba, IV - Minusinsk. KR - Krasnoyarsk reservoir. Devonian, Carboniferous, Permian, and Jurassic sedimentary rocks.

initial stages of the Earth's crustal extension. This scheme is often applied to the magmatism of continental paleorifts and rift-like structures. Therefore, the homodromous scheme of volcanism (magmatic rocks are formed from mafic to felsic magmatites) and the concepts of volcanosedimentary cycles are commonly assumed. However, this statement contradicts the facts. For instance, Gans et al. (1989) showed that basalts of the classical Basin and Range Province in North America are younger than felsic-andesitic volcanic rocks.

The second reason lies in the improper interpretation by some researchers of particular features, distinguishing the strata-like bodies as extrusive flows versus intrusive sills. These bodies are often regarded as volcanic in origin, because of their association with tuffs and tufogenic strata. Glassy texture and columnar jointing, vesicular endocontacts and near-contact breccias are thought to be typical of lava flows. However, some geologists have cast doubts on the absoluteness of this interpretation (Lahee 1923). Such an error arose from confusing the features of lava flows and shallower-depth sills.

The third reason is a poor understanding of the dynamics and rheological properties of mafic magma as it injects into host rocks along nearly horizontal pathways. The processes of magmatic intrusion (sills) into sedimentary cover has previously been poorly understood. Unfortunately, earlier concepts which have been offered for similar conditions describe only some of the processes operating at the contact zones of hypabyssal sills (Sharapov \& Golubev 1976, Cherepanov et al. 1996). These models suggest 'instantaneous' filling of the space (chamber) in sedimentary successions. Paradoxes arise as a consequence of the contradiction between the expected high-temperature transformations and observed geological facts, which are indicative of moderate-temperature processes. To overcome those difficulties, the top contacts of bedded mafic rocks should be carefully studied. A new model implies 'warm' contacts with rocks that are altered to a porcelaneous texture and hydrothermally-altered host rocks instead of 'hot' contacts hornfelses and skarns (Fedoseev 2004a). The interaction between cooling magma and a relatively low degree of heating up host rocks of variable composition leads to formation of specific rocks and textures such as rheological breccia, plastic autobreccia, and magma-rock mixtures (mixtites). Roller-like textures (rheological 'waves' that appear in the upper contact zone of sills and trap host rocks), destructive and plastic deformation of xenoliths, and structures of rheological differentiations can commonly occur in shallow intrusions. Roller-like texture is one of the forms of underground fragmentation of basalt melt. Neither stratigraphers nor petrologists tend to be familiar with these more subtle features, which have become more apparent through closer analysis of magmatic rheology, melt dynamics, hydrogeodynamics and lithogeodynamics (Fedoseev 2004b).

\section{Stratigraphic position of mafic sills}

The Minusa Trough consists of several depressions filled with Devonian, Carboniferous, Permian, and Jurassic sedimentary rocks (Fig. 1). The Lower Devonian Series discordantly overlies a Riphean to Cambrian carbonate and volcanogenicterrigeneous-carbonate succession and is overlain by Middle Devonian sedimentary rocks (Ilemorovo, Saragash, and Beya formations). Geological mapping, at $1: 200000$ and $1: 50000$ scales, has revealed no Ordovician sediments in the area of interest (Rublev et al. 1999 mistakenly identified the lower part of the Devonian succession as Ordovician).

In the Shunet-Matarak region (see Fig. 2), the deposits of the Byskar succession are represented (from bottom to top) by the Matarak, Shunet, and Aramchak formations. 
There are conventional contacts between these units (Fig. 2A). The lower part of the Lower Matarak Formation is composed of lilac and lilac-brown lithoclastic tuffs, which are sometimes termed the Imirskaya Formation. The tuffs of essentially andesitic-rhyolitic-rhyodacitic composition frequently overlie conglomerates, and sandstones. Overlying is a red terrigeneous succession that has a rhythmic structure and contains relicts of an Early Devonian flora; individual, thin (up to 3-4 m) horizons of ash tuff are found. The upper subdivision of the Matarak Formation begins with a distinct, 12-15 m-thick tuff-breccia unit. It changes upward into green-gray and dark green lithoclastic tuffs, which are in turn overlain by red-colored terrigenous rocks. Upsection, the upper part of the Matarak Formation gradually passes into the green-gray Shunet Formation, which is composed of green siltstone. The middle and upper parts of this formation consist of $4-5 \mathrm{~m}$ of dolomitic marl, while the lower part is composed of 2-3 m of quartz sandstone. Red beds of the succeeding Aramchak Formation (conglomerates, sandstones, and siltstones) conformably overlie the rocks of the Shunet Formation.

Two sill complexes termed Kuzme and Ust-Koksa are distinguished within the Minusa Trough. The first complex is composed of fine-grained dolerites and endocontact basalt. Two dolerite sills 3 and $12 \mathrm{~m}$ thick occur intralayered with siltstones of the Shunet Formation on the north side of Lake Shunet (Fig. 2B). Four dolerite sills of 8 up to $40 \mathrm{~m}$ in thickness occur in sandstones in the lower part of the Matarak Formation (Fig. 2C). Xenolith blocks entrapped by vesicular basalt were found in the Matarak-2 sill. The Ust-Koksa complex is composed of porphyry that contains up to $70-80 \%$ plagioclase phenocrysts. Direct sill contacts with terrigeneous rocks are of fundamental importance. Sometimes mafic bodies occur inside the layers, which have essentially identical compositions (see Fig. 2B). This is indirect evidence of the intrusive nature of the magmatites.

No reliably established mafic bodies have been found within the Aramchak Formation. However, the geological setting is quite favorable for their existence. Therefore, a further search for mafic bodies in correlative rocks in adjacent areas is of great importance.

\section{Specific properties of mafic flows and undifferentiated sills}

Whereas the study of active and extinct volcanoes allows reconstruction of the character of volcanic activity, models for the formation of shallow-depth, bedded intrusions are still poorly developed. Therefore, the problem of distinguishing eruptive from subhorizontally intrusive magma is significant. Resolution is complicated by the fact that for the majority of researchers extrusion and intrusion are essentially alternative processes. Therefore, identifying ap-

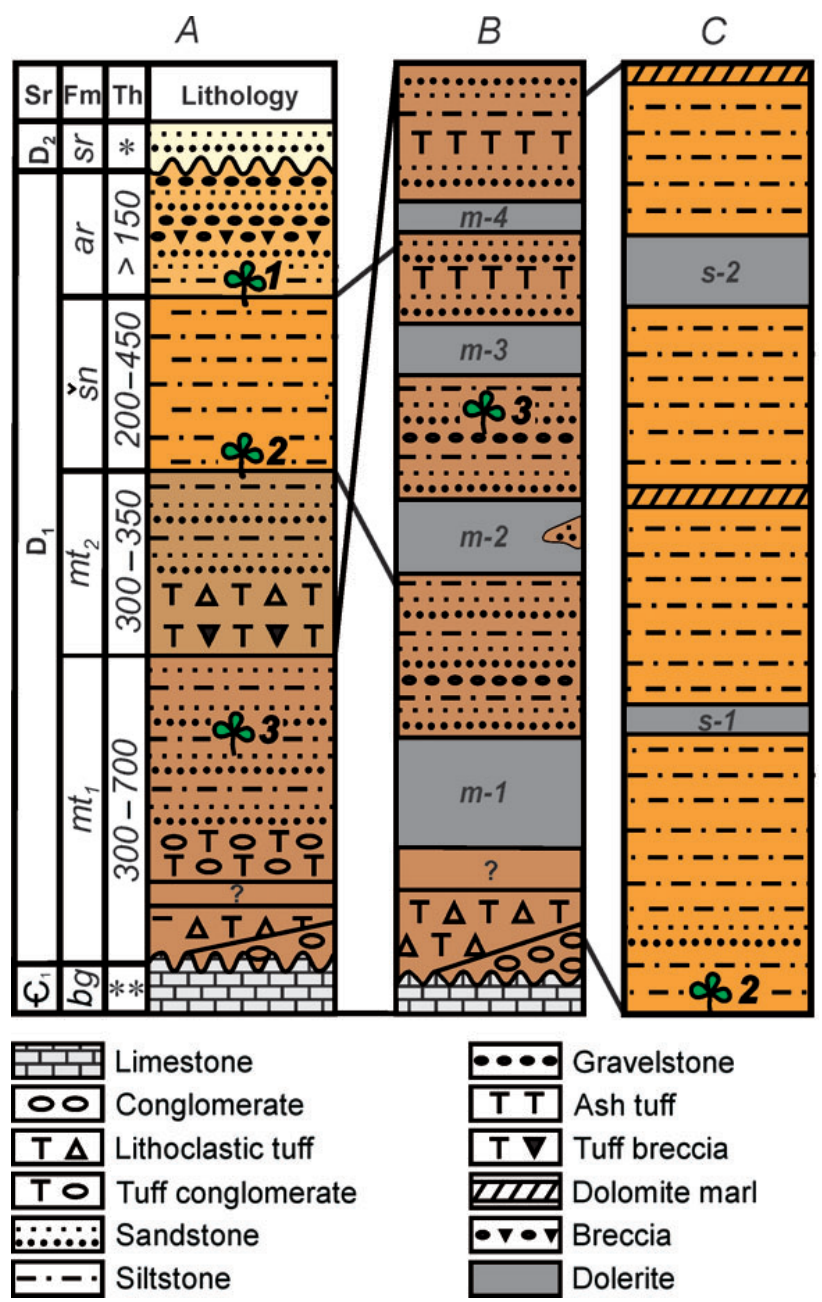

Figure 2. Lithostratigraphic section of the Shunet-Matarak district, and its intervals. A - generalized section through the Lower Devonian with marked levels of fossil flora, B - interval of Matarak sills, C - interval of Shunet sills. Sr - Series, Fm - Formation, Th - thickness, $\mathrm{m}\left(*_{-}>100 \mathrm{~m}\right.$, $* *$ - > $3000 \mathrm{~m}$, “?" - unknown thickness). Formations (up section): bg - Bograd $\left(C_{1}\right)$; Byskar succession $\left(D_{1}\right): m t-$ Matarak $\left(m_{2}-\right.$ Upper subdivision, $\mathrm{mt}_{1}$ - Lower subdivision), šn - Shunet, ar - Aramchak; sr - Saragash $\left(\mathrm{D}_{2}\right)$. Flora occurrences (Ananiev 1959): 1 - Shunet, 2 - Kaskyr, 3 - Matarak.

propriate distinguishing features is very significant. It is assumed, for example, that intrusive magma of basic composition must cause high-temperature contact metamorphism. In addition, magma should not cool to glass and, in particular, should not contain numerous gas bubbles. Moreover, the ability of magma to form necessarily the dikes and apophyses in the roof part of magmatic chambers is prescribed to mafic magmatic melt. The author has established that in the upper exocontact there is a layer of 'plastic' rocks, which hinder fracturing and fill other structures with melt. When trying to distinguish volcanic from shallow intrusive rocks, many geologists do not realize that many features of bedded igneous bodies are inherent in both flows and sills. Therefore, a comprehensive study is 
required to distinguish ball or sphere-like (pillow) lavas in lava flows from the roller macrostructures in sills. Oxidized (due to lava-air interaction) volcanic rocks in lava flows versus bleached, spilitized basalts from endocontacts of bedded bodies are also difficult to distinguish and intricately deformed xenoliths of sedimentary rocks in basalt sills can easily be confused with siliceous deposits in lava flows or clastic (sedimentary) dikes.

Thus, recognition of the mafic bedded bodies occurring within sedimentary and volcano-sedimentary deposits depends on study of their upper contacts. Without such analyses, the above-mentioned errors lead to incorrect conclusions on the nature of shallowly-intruded mafic rocks.

Key distinctive features of effusive flows include scoria-hyaline breccias, surface and foot crusts, pillow lavas, traces of erosion, the flow surface, and its subsequent burial, volcanic bombs that have stuck to the surface of the lava flow, and more. As the dynamics of lava flows and sheets are determined solely by the gravitational forces, their distribution is controlled by paleorelief. Therefore, one distinguishing feature of extrusive flows is the sequence and filling of paleodepressions with lava. Detailed cross sections play an important role in the identification of flows, since they record the sequence of flows over lava plateaus. Note that it is also very important to establish a direct relationship of flows with craters and fractured feeding canals.

Vesicular and amygdaloidal structures, glassy structures, prismatic jointing, gas channels, and other features should be neglected in facies diagnosis. Detailed analyses indicate that these features are convergent, and occur in both extrusive and shallowly intrusive settings.

Shallow-depth non-differentiated sills are characterized by another set of divergent features, which are found by detailed study of the upper contacts of intrusive bodies: a) subvertical basalt injections having complicated forms; b) large blocks of terrigenous rocks inside the basalt and porphyry bodies; c) magmatic autobreccias the lenses of which occur along the contacts; d) deformed xenoliths of sedimentary and volcano-sedimentary rocks having intricate outlines; e) roller textures accompanied by trapping and expanding of roof rocks; f) stable alternation of mafic bedded bodies and the layers of terrigenous rocks; g) different types of 'warm' upper contacts determined by the various compositions of host rocks. Specific features of some upper sill contacts, as seen in the Devonian succession exposed on the shores of the Krasnoyarsk reservoir and adjacent territories (Fig. 1), include complex configurations with various characters dependent on the composition of the host rock. One key feature is subvertical injections of vesicular basalt, which cut the borders of variously grained layers in host rocks and have intricate outlines (Fig. 3A). Injections of magma into the roof rocks (Fig. 3B) are often seen. A variety of this injection type is generated by the interaction of magmatic melt and a siltstone layer (Fig. 3C, D). The siltstone is thermally altered to a rock with a porcelaneous texture.

One problem with these features, however, is that the upper contacts of the bedded bodies are usually poorly preserved. They are destroyed rapidly under tropical climatic conditions, and thick weathering crusts form. These features are also difficult to recognize in permafrost regions, where basalts and dolerites serve as aquatards or aquacludes for groundwater during the intense snow thawing. In areas with a temperate climate, the top contacts are sometimes preserved under the cuesta scarps. Such regions, where erosion processes keep pace with weathering, are especially suitable for the study of upper sill contacts. On flat slopes, the contacts are often covered by turf and the products of rock weathering. Therefore, exposed contacts are best seen in mines and trenches. In the fresh walls of such workings, one can clearly observe the history of active intrusion of magmatic melt.

Large xenoliths of sedimentary and sedimentary-volcanogenic rocks are found inside the mafic intrusions. Their orientation is generally concordant with the contacts. In some areas, xenolith content can reach 10 vol.\%. Small roof exfoliations can deform and change orientation. Quite often they are vertically oriented and misinterpreted as clastic dikes. The spatial relationship between the xenoliths and exfoliations from the roof can be clearly observed. They have complex forms, due to significant plastic deformation within the magma (Fig. 3E, F). This fact can be explained by interpreting the plastic flow of sedimentary material as caused by viscous magma. Injections of magmatic material into xenoliths are rarely observed (Fig. 3G). In the upper exocontacts of some bedded bodies small folds occur; the folded layers may pinch and swell horizontally along the contact. In some sills, calcite spherulites can also occur widely in the exocontact zones, a result of the recrystallization of carbonate material under moderate temperature and pressure conditions (Fig. $3 \mathrm{H}$ ).

\section{Timing of sill injection}

The timing of the injection of the mafic sills is estimated based on geological, paleontological and geochronological data. Each is discussed separately below.

Figure 3. Relationship of Lower Devonian sedimentary rocks and mafic sills, at upper sill contacts. $\bullet$ A - sublayer injection of amygdaloidal basalt in sandstones (Sisim sill, outcrop). • B - injection of mafic magma in sandstones (Matarak-3 sill, outcrop, photo by V.M. Kalugin). • C, D - series of microinjections into porcelaneous siltstone (Sisim sill, samples). $\bullet$ E, F - plastic macrostructures (Ust-Koksa sill, outcrop). $\bullet$ G - xenolith of lamestone into dolerite (Sisim sill, outcrop). $\bullet \mathrm{H}-$ calcitic spherulites in sandstone (Sisim sill, samples). 
Geliy S. Fedoseev • The role of mafic magmatism in age specification of Devonian continental trough deposits
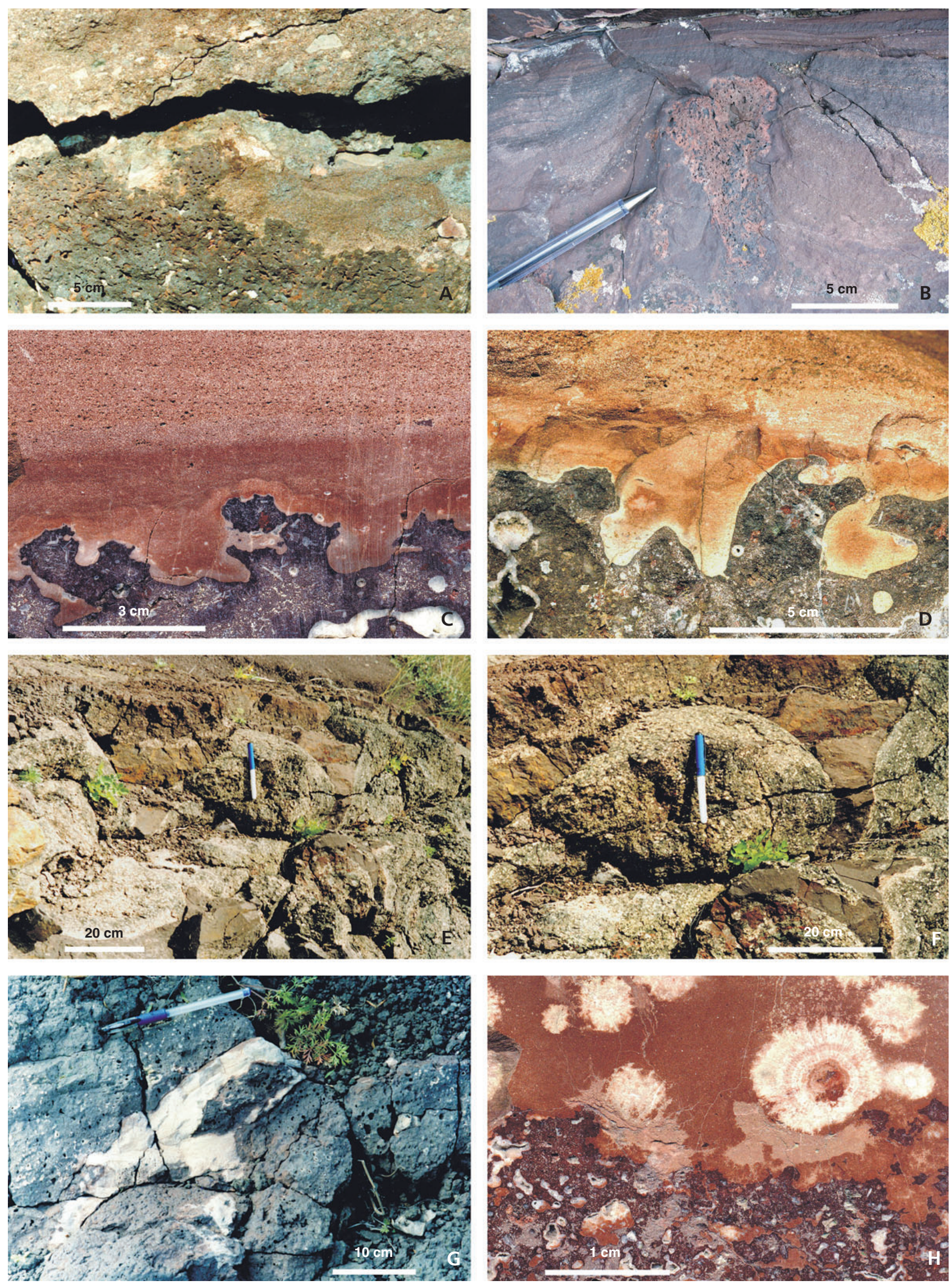


\section{Geological data}

Geologists studying the Minusa Trough over a long period have established that the Byskar volcano-sedimentary succession, including the mafic sills of the Kuzme and Ust-Koksa complexes, is of Early Devonian age (Ananiev 1959, 1968; Sennikov et al. 1995; Kruk 2002; Babin et al. 2004). The 'series' is separated from under- and overlying formations by regional stratigraphic disconformities. The upper age boundary of sill intrusion is determined by an angular unconformity between the Byskar succession and the overlying Middle Devonian Saragash and Beya formations. However, the Byskar volcano-sedimentary rocks and associated sills were deformed before they were overlapped by the Middle Devonian Series. This implies a significant break in sedimentation. The lower bounding age is determined by the nonconformable lower contact of the Byskar succession with complexly deformed and metamorphosed Lower Cambrian strata (Bograd Formation), which is intruded by granitoids. Basal conglomerates in the base of the Byskar succession suggest long weathering and erosion of basement rocks prior to Early Devonian sedimentation.

\section{Paleontological data}

A great time span of formation (from Early Cambrian to Middle Devonian) of the Byskar succession established during the geological study has subsequently been defined more exactly by paleontological methods. Most of the floral data (Table 1) were made in the Shunet-Matarak and Kaskyr districts (Ananiev 1959, 1960, 1968; Krasnov et al. 1975; Zakharova \& Ananiev 1990; Sennikov et al. 1995).

According to the paleobotanical findings, the Byskar succession hosting all mafic magmatites was formed in the Early Devonian. The plant identifications allowed a better understanding of the problem of the age relationship between the mafic magmatites and the volcano-sedimentary formations. The age range was narrowed to one period (Devonian) and even epoch (Early Devonian). This is a more precise definition, which implies that mafic magmatites, on the one hand, might also be Early Devonian (if the opinion that they are effusive formations be accepted). On the other hand, the magmatites can turn out to be intrusive bodies. In this case their absolute age cannot be older than Lochkovian because there is no paleontological evidence for Silurian discovered in the Minusa Basin.

\section{Geochronological data}

The traditional interpretation of the mafic bedded bodies of the Minusa Trough as shown in stratigraphic columns, is that they are of volcanic origin (Luchitskiy 1960, Kovalev
Table 1. Early Devonian flora from the Shunet-Matarak and Kaskyr districts, Minusa Intermountain Trough, western Siberia. Abbreviation: Fm. - Formation

\begin{tabular}{|c|c|c|}
\hline Fm. & Flora & Age \\
\hline 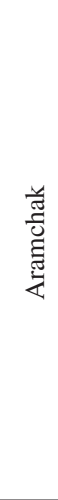 & $\begin{array}{l}\text { Chakassiophyton krasnovii Ananiev } \\
\text { Dawsonites arcuatus Halle } \\
\text { Drepanophycus spinaeformis Goeppert } \\
\text { Hostimella hostimensis Potonie \& Bernard } \\
\text { Margophyton goldschmidtii (Halle) Zakharova } \\
\text { Minusia antiqua Tschirkova } \\
\text { Pectinophyton norvegicum Hoeg } \\
\text { Psilophyton princeps Dawson } \\
\text { Sawdonia ornata (Dawson) Hueber } \\
\text { Taeniocrada decheniana Krausel \& Weyland } \\
\text { Zosterophyllum cf. australianum Lang \& Cooks }\end{array}$ & 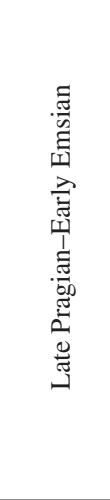 \\
\hline 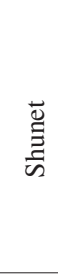 & $\begin{array}{l}\text { Bucheria dawsonii (Kräusel \& Weyland) } \\
\text { Cooksonia rusanovii Ananiev } \\
\text { Distichophytum mucronatum Mägdefrau } \\
\text { Protobarinophyton obrutschevii Ananiev } \\
\text { Zosterophyllum myretonianum Penhallow } \\
\text { Zosterophyllum rhenanum Kräusel \& Weyland }\end{array}$ & 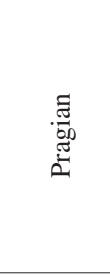 \\
\hline 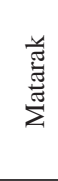 & $\begin{array}{l}\text { Angarolaminariopsis zinovae Ananiev } \\
\text { Protobarinophyton obrutschevii Ananiev } \\
\text { Psilophyton goldschmidtii Halle } \\
\text { Stylonurus ruedemanni Störmer }\end{array}$ & 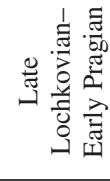 \\
\hline
\end{tabular}

1980). Hence, their age should correspond to the sequence of sedimentation. In fact, the first K/Ar dating obtained by Zubkov et al. (1986) did not contradict this point of view (Table 2). Rublev et al. (1999) constrained the age of the formation from $357 \pm 15$ Mya (after plagioclase) to $406 \pm$ 16 Mya (after pyroxene). A single determination of the basalt age, using the ${ }^{40} \mathrm{Ar} /{ }^{39} \mathrm{Ar}$ method, yielded $392 \pm 11$ Mya (Malkovets 2001).

Fedoseev et al. (2003) have established that porphyry dikes cross-cut bedded bodies of both porphyry (Volchiy Log or 'Wolf Valley', near the Koksa river), and dolerites (Kopievskiy dome, near Malyi Syutik). The ${ }^{40} \mathrm{Ar} /{ }^{39} \mathrm{Ar}$ age of these igneous structures appears to be the youngest ( $385 \pm 4$ Mya). The same method was used to determine the bedded mafic rocks. It should be noted that the ages of the Kuzme and Ust-Koksa complexes are essentially the same.

The available isotope-geochronological data suggest that sedimentation and mafic magmatism were penecontemporaneous (magmatism after sedimentation) in time and spatially conjugated. One can assume the coexistence of two separate magmatic centers delivering magma for the formation of dolerites and porphyry, respectively. The first center operated within the time span of Ludlovian up to Eifelian, while the second for porphyry existing from Pragian to Eifelian (Kaufmann 2006). However, a large 
Geliy S. Fedoseev • The role of mafic magmatism in age specification of Devonian continental trough deposits

Table 2. Isotopic ages of intrusive and pyroclastic rocks of the Minusa Basin, western Siberia

\begin{tabular}{|c|c|c|c|c|c|c|c|}
\hline No. & sample & locality & rock type & analyzed material & age $(\mathrm{Ma})$ & isotope pair & reference \\
\hline 1 & UZ-441 & Tuim river & alkaline olivine basalt & rock & $383 \pm 39$ & $\mathrm{Rb} / \mathrm{Sr}^{1)}$ & Zubkov et al. (1986) \\
\hline 2 & $\mathrm{R}-472$ & Shumikha river outfall & basalt & pyroxene & $406 \pm 16$ & $\mathrm{~K} / \mathrm{Ar}^{2)}$ & Rublev et al. (1999) \\
\hline 3 & $\mathrm{R}-472$ & Shumikha river outfall & basalt & plagioclase & $357 \pm 15$ & $\mathrm{~K} / \mathrm{Ar}^{2)}$ & \\
\hline 4 & HK-1 & Erba depression & basalt & rock & $392 \pm 11$ & ${ }^{40} \mathrm{Ar} /{ }^{39} \mathrm{Ar}^{3)}$ & Malkovets (2001) \\
\hline 5 & КК-1 & South outskirts of Shira village & dolerite & rock & $386 \pm 4$ & ${ }^{40} \mathrm{Ar}{ }^{39} \mathrm{Ar}^{3)}$ & Fedoseev et al. (2003) \\
\hline 6 & $76 \mathrm{R}$ & West outskirts of Shira village & dolerite & rock & $395 \pm 2$ & ${ }^{40} \mathrm{Ar}{ }^{39} \mathrm{Ar}^{3)}$ & \\
\hline 7 & $169 \mathrm{R}$ & Sisim river outfall & dolerite & rock & $422 \pm 4$ & ${ }^{40} \mathrm{Ar}{ }^{39} \mathrm{Ar}^{3)}$ & \\
\hline 8 & $80 \mathrm{R}$ & Koksa river outfall & porphyry & rock & $405 \pm 3$ & ${ }^{40} \mathrm{Ar}{ }^{39} \mathrm{Ar}^{3)}$ & Fedoseev et al. (2003) \\
\hline 9 & $88 \mathrm{p}$ & Koksa river outfall & porphyry & rock & $385 \pm 4$ & ${ }^{40} \mathrm{Ar}{ }^{39} \mathrm{Ar}^{3)}$ & \\
\hline 10 & $160 \mathrm{R}$ & Bolshoi Imir mountain & porphyry & rock & $402 \pm 4$ & ${ }^{40} \mathrm{Ar}{ }^{39} \mathrm{Ar}^{3)}$ & Fedoseev et al. (2003) \\
\hline 11 & $\begin{array}{l}\text { R-466 } \\
\text { R-468 } \\
\text { R-471 }\end{array}$ & Enisey cross-section & trachydacite & rock & $448 \pm 7$ & $\mathrm{Rb} / \mathrm{Sr}^{2)}$ & Rublev et al. (1999) \\
\hline 12 & Several & Enisey cross-section & trachydacite & feldspar (5), rock (3) */ & $414 \pm 5$ & $\mathrm{Rb} / \mathrm{Sr}^{2)}$ & \\
\hline 13 & S-21-1 & Sisim river outfall & trachyrhyodacite (dike) & zircon & $407.5 \pm 0.2$ & $\mathrm{U} / \mathrm{Pb}^{4)}$ & Kruk et al. (2002) \\
\hline
\end{tabular}

Notes: Sample numbers correspond to numbers on map (Fig. 1). Analyses were carried out in: ${ }^{1)}$ - Analytic Department of the Institute of Geochemistry of SB RAS, Irkutsk (analyst V.V. Ershov); ${ }^{2}$ - Department of Isotopic Geology at All-Union Geological Institute (VSEGEI), Saint-Petersburg (analyst A.G. Rublev); ${ }^{3)}$ - Laboratory of Radiogenic and Stable Isotopes at the Analytical Center of the United Institute of Geology, Geophysics and Mineralogy SB RAS (UIGGM), Novosibirsk (analyst A.V. Travin); ${ }^{4)}$ - Institute of Isotopic Geochronology and Mineral Resources, Zürich (analyst S.A. Sergeev). 1-7 - Kuzme complex; 8, 9 - Ust-Koksa complex; 10-13 - Imir Formation: */ - feldspar (sample numbers: R-466, R-468, R-469, R-470, and R-471) and rocks (sample numbers: R-469, R-470, and 220520).

scatter in the geochronological data obtained from the layered mafic rocks does not permit resolution of the problem.

More accurate results for the volcanogenic layers in the Imirskaya Formation have been obtained using different techniques. According to Rublev et al. (1999), the $\mathrm{Rb} / \mathrm{Sr}$ age of the suite is $448 \pm 7$ and $414 \pm 5$ Mya for the three and eight determinations, respectively. Later, Babin et al. (2004) more accurately dated the age of the volcanics using the $\mathrm{U} / \mathrm{Pb}$ method (407.5 $\pm 0.2 \mathrm{Mya})$. According to Fedoseev et al. (2003), the ${ }^{40} \mathrm{Ar} /{ }^{39} \mathrm{Ar}$ age of "plagioporphyries' from the Imirskaya Formation is $402 \pm 4$ Mya. Thus, the geochronological data suggest an Emsian age for the Byskar succession. However, an older Silurian to earlier Devonian age for its lower part cannot be ruled out.

Thus, the K/Ar and $\mathrm{Rb} / \mathrm{Sr}$ geochronological methods appear inappropriate for dating both intrusive mafic rocks and pyroclastic rocks of acidic composition. The $\mathrm{Rb} / \mathrm{Sr}$ method is assumed to record only the last temperature effects exerted on minerals, which reset the isotopic system. The ${ }^{40} \mathrm{Ar} /{ }^{39} \mathrm{Ar}$ method gives more accurate results, with an acceptable analytical error. However, even this method is not sufficient enough to delineate definitively the timing of sedimentation of the volcano-sedimentary succession from the timing of intrusions. Hence, data obtained by the U/Pb method, characterized by high stability and reliability, should provide the most accurate age dates. Therefore, the Late Ordovician age of the Imir volcanites (Rublev et al. $1999, \mathrm{Rb} / \mathrm{Sr}$ method), obtained by this method is also doubtful (Kruk et al. 2002).

\section{Conclusions}

The Devonian mafic bedded bodies, which were earlier interpreted as effusive deposits within the Minusa Intermountain Trough, are shown to have an intrusive origin. This allows a better estimation of the true thickness of stratigraphic sections and resolution of problems of facies variation in the succession of the Lower Devonian deposits. Hence, Devonian stratigraphy and reconstruction of Early Devonian paleosettings within the Central Asian Orogenic Belt requires reexamination.

Geological, paleontological, and isotope-geochronological data suggest that the major injection of mafic magma into the volcano-sedimentary and sedimentary succession occurred during the Emsian stage. Two magmatic centers are proposed: the first was responsible for the formation of the Kuzme basalt and dolerite complex; the second produced the Ust-Koksa porphyry complex. The wide distribution of these magmatic complexes within the Devonian depressions in the northwestern part of the Central Asian Belt is indirect evidence for the existence of a large intracontinental sedimentary paleobasin, which originated at the time of the Silurian-Devonian boundary.

\section{Acknowledgements}

The work was financially supported by grant RFBR 07-05-00664 and the Complex integration projects of the Presidium of the Si- 
berian Branch of the Russian Academy of Sciences (SB RAS) 6.4 and 6.11. This is a contribution to UNESCO-IUGS IGCP Project 499 "Devonian Land-Sea Interaction: Evolution of Ecosystems and Climate. I am grateful to E.A. Yolkin, V.I. Krasnov, L.S. Ratanov, N.V. Sennikov, N.G. Izokh, I.Y. Saphonova, O.T. Obut, and V.S. Gimon for their helpful comments and discussions. The author would like to thank C.A. van Straeten, P. Königshof, B. Kaufmann, and S. Turner for their critical and constructive reviews, which significantly improved the quality of the paper.

\section{References}

ANANIEV, A.R. 1959. Major locations of the Devonian floras at the Altai-Sayan mountain area. 115 pp., Tomsk.

ANANIEV, A.R. 1960. Thelomophyta. The highest plants, 578-599. In KHALPHIN, L.L. (ed.) Paleozoic biostratigraphy of the AltaiSayan mountain area. Middle Paleozoic II(20). Novosibirsk.

ANANIEV, A.R. 1968. New dates for stratigraphy of continental Devonian sediments of the Western Siberian, 96-103. In IVANIYA, V.A. (ed.) Trudi of Tomsk State University 202 (geological series). Tomsk.

Babin, G.A., Vladimirov, A.G., KrUK, N.N., CERGEeV, S.A., SENNIKOV, N.V., GibShER, A.S. \& SOVETOV, Y.K. 2004. Age of Minusa depressions location (Southern Siberian). Dokladi akademii nauk 395(3), 367-370.

Cherepanov, A.N., Sharapov, V.N. \& Popov, V.N. 1996. Dynamics of the cooling of basic melt during as magma chambers fill. Geologiya i geofyzica 37(7), 44-56.

FedoseEV, G.S. 2004a. Identification of mafic paleoflows and sills on the continents, 134-137. In SKLAYROV, E.V. (ed.) Geodynamic evolution of lithosphere of Central Asian mobile belt (from Ocean to the Continent) 2(2). Irkutsk.

FEDOSEEV, G.S. 2004b. Intraplate mafic sill genesis - an alternative to flood basalt volcanicity, 199-200 (text), 228 (ill.). In CHERKASOv, S. (ed.) Science and our future: ideas to change the world. Moscow.

FEDOSEEV, G.S. 2008. Continental sills formation as an indicator of mantle plume manifestation. Abstracts of 33IGC, CD: session MPI-05 Large Igneous Provinces: Initiation, evolution and origin. Oslo, Norway. http://www.33igc.org/coco/Handlers $/ \mathrm{COCO} /$ Sear-ch.aspx $?$ PageID $=5002 \&$ time $=2 \&$ date $=3 \#$

Fedoseev, G.S., RATANOV, L.S. \& Travin, A.V. 2003. ${ }^{40} \mathrm{Ar} /{ }^{39} \mathrm{Ar}$ dating of a sill complexes and volcanites at the Minusa intermountain depression (West Siberia), 518-521. In KoZAKOV, I.K. \& KoTOV, A.B. (eds) Isotopic geochronology in decision of a geodynamic and ore genesis problems. Saint-Petersburg.

Gans, P.B., Mahood, G.A. \& SCHERMER, E. 1989. Synextensional magmatism in the Basin and Range Province: a case study from the Eastern Great Basin. Geological Society of America Special Paper 233, 3-58.

KaufmanN, B. 2006. Calibrating the Devonian Time Scale: a synthesis of U-Pb ID-TIMS ages and conodont stratigraphy. Earth Science Reviews 76, 175-190. DOI 10.1016/j.earscirev.2006.01.001
KovaleV, V.P. 1980. Hercynian magmatism of Predsayania (radiogeochemistry, petrology, reconstructions). 424 pp., Novosibirsk.

Krasnov, V.I. \& FedoseEv, G.S. 2000. Byskar Series of the Minusa intermountain depression: modern interpretation (to the improvement of legend of Gosgeolmap-200 and -1000), 93-99. In KRASNOV, V.I. (ed.) Stratigraphy and Paleontology of Siberia. Novosibirsk.

KRASNOV, V.I. \& RATANOV, L.S. 1972. On the structure of Devonian volcanogenic-sedimentary complex in the Minusa trough, 88-92. In SUKHOV, S.V. \& KRASNOV, V.I. (eds) Materiali on Stratigraphy and Paleontology of Siberia 146. Novosibirsk.

Krasnov, V.I., RATANOV, L.S., ASTASChKIN, V.F. \& MiRONOVA, M.F. 1975. Some problems to theories and practice of regional stratigraphy on example of the study Devonian formations in Altai-Sayan area, 25-44. In KRASNOV, V.I. (ed.) Materials for regional geology of Siberian 216. Novosibirsk.

KruK, N.N., BABIN, G.A., Vladimirov, A.G., RudnEV, S.N., Gibsher, A.S., Sovetov, Y.K., Sergeev, S.A., Kotov, A.B., SAlnikova, E.B., LeVChENKo, O.A., MAKhlaEy, E.M. \& DERBAN, A.G. 2002. Devonian-like magmatism of East Sayan (U-Pb isotopic researches), 189-193. In CHERNYSHOV, A.I. (ed.) Petrology of magmatic and metamorphic complexes 3(1). Tomsk.

LAHEE, F.H. 1923. Field Geology. 651 pp. McGraw-Hill Book Company, New York \& London.

LEVCHENKO, S.V. 1975. Before platform metallogeny of the Kuznetsk-Minussa ore region. 192 pp. A.A. Arsenev, Moscow.

LUCHITSKIY, I.V. 1960. Volcanism and tectonics of the Devonian depressions of the Minusa Intermountain Trough. 276 pp. Y.A. Kuznetsov, Moscow.

MALKOVETS, V.G. 2001. Composition and structure of Mesozoic Upper Mantle under North Minusa trough. 24 pp. Abstract of Ph.D., Institute of Geology SB RAN, Novosibirsk, Russia.

RubleV, A.G., SherginA, Y.P., BERZON, E.I., BARSEGYAN, V.E., LEVCHENKOV, O.A. \& YAKOVLEVA, S.S. 1999. Isotopic age of the paleozoic volcanites at the Krasnoyarsk elevation and stratigraphy problems of the Byskar Series. Otechestvennaia geologia 3, 47-54.

SHARAPOV, V.N. \& GOLUBEV, V.S. 1976. The dynamics of interaction between magma and rocks. 237 pp. Y.A., Novosibirsk.

SENNiKov, N.V., GRatsianova, R.T., SObOlEV, E.S. \& KLETS, T.V. 1995. On genesis and age of the Aramchak formation of the Lower Devonian in the North-Minusa depression. Geology and Geophysics 36(3), 15-24.

ZAKHAROVA, T.V. \& ANANIEV, A.R. 1990. On stratigraphic position of Devonian Byskar Series at Minusa trough. Bulletin of Moscow Society of Nature investigators. Department of Geology 65(2), 44-50.

Zubkov, V.S., PaKholchenko, Y.A., SAndimirova, G.P., MAMITKO, V.R. \& PLYUSNIN, G.S. 1986. Rubidium- strontium age and genesis of alkaline olivine basalt of the Minusa trough systems. Dokladi akademii nauk of USSR 290(4), 960-963. 